\title{
А.С. Голобоков
}

Владивостокский государственный университет экономики и сервиса

Владивосток. Россия

\section{Основные тенденции военно-политического сотрудничества России с Индией и странами Юго-Восточной Азии}

\begin{abstract}
В статье исследованы вопросы военно-политического сотрудничества России с Индией и странами Юго-Восточной Азии. Цель работы состоит в том, чтобы проанализировать динамику и характер военно-морских учений России с Индией, Вьетнамом и Филиппинами, Таиландом, Мьянмой, Камбоджей и Лаосом за последние годы и изучить масштабы диверсификации российской военно-морской деятельности в регионе. Актуальность исследования состоит в неоднозначности оценки двустороннего и многостороннего военно-политического сотрудничества России со странами ATP, которое определяется не только общими политическим и экономическим мотивами, но и направлено на решение целого комплекса актуальных задач, сформированных вызовами региональной безопасности в Юго-Восточной Азии и Индийском океане. Предложенный подход состоит в многофакторном анализе динамики военно-политического сотрудничества, отраженного в официальных документах и сообщениях СМИ, действий заинтересованных сторон и результатов проведения совместных мероприятий. Сделан вывод о том, что Россия демонстрирует интерес к многостороннему формату военно-морского сотрудничества и одновременно оказывает влияние на региональную безопасность и баланс сил в регионе. В то же время с укреплением стратегического партнерства между Китаем и Россией уровень взаимодействия России со странами ЮВА напрямую отражает уровень политического партнерства. Значимость исследования состоит в анализе особенностей военно-морского взаимодействия России со странами Юго-Восточной Азии с учетом изменяющегося в сторону азиатских государств баланса сил и угроз в ИндоАзиатском регионе. Результатом этого взаимодействия является увеличение частоты, масштабов и диверсификации российской военно-морской деятельности в ЮгоВосточной Азии при сохранении динамики военно-морских контактов. Результаты данной работы представляют ценность для политиков, дипломатов, ученых, изучающих возможность создания модели безопасности в АТP.
\end{abstract}

Ключевые слова и словосочетания: Азиатско-Тихоокеанский регион, стратегическое партнерство, военно-морское сотрудничество, региональная безопасность,

Голобоков Андрей Сергеевич - канд. полит. наук, доцент кафедры экономики и управления; e-mail: golobokov_as@mail.ru

128 
национальный интерес, международные отношения, Россия, Индия, военноморские учения, национальная политика, США.

\title{
A.S. Golobokov
}

Vladivostok State University of Economics and Service

Vladivostok. Russia

\section{The main trends of Russia's military-political cooperation with India and Southeast Asian countries}

\begin{abstract}
The paper reviews various features of energy cooperation of Russia with India and the Southeast Asian countries. The goal is to analyze the features of Russian naval exercises with India, Vietnam and the Philippines, Thailand, Myanmar, Cambodia and Laos in recent years, considering diversification of Russian activities in the region. The research is topical due to ambiguity of the assessment of bilateral and multilateral military-political cooperation between Russia and the Asia-Pacific countries, and is determined not only by general political and economic motives, but also aimed at solving a whole range of urgent tasks formed by the challenges of regional security in Southeast Asia and the Indian Ocean. Multiple-factor analysis on the dynamics of military-political cooperation reflected in official documents and media reports, the actions of stakeholders and the results of joint activities proposed. The conclusion is made, that Russia demonstrates interest in the multilateral format of naval cooperation and at the same time influences regional security and the balance of forces in the region. Along with the strengthening of the strategic partnership between China and Russia, the level of interaction between Russia and the countries of Southeast Asia directly reflects the level of political partnership. The significance of the work is in analysis of naval interaction between Russia and the countries of Southeast Asia, given the changing balance of forces and threats in the direction of the Asian states in the Indo-Asian region. The results are valuable to politicians, diplomats, scientists studying the security model in the Asia-Pacific region.
\end{abstract}

Keywords: Asia-Pacific region, strategic partnership, naval cooperation, regional security, national interest, international relations, Russia, India, naval exercises, national policy, U.S.

Развитие сотрудничества России со странами Азиатско-Тихоокеанского региона в последние годы демонстрирует, что наиболее динамичным направлением остаются военно-дипломатические отношения России и Китая. Некоторые их элементы, в частности военно-морские учения, вызывают обеспокоенность военного и политического командования США [19]. В 2019 г. Россия и Китай усилили свое военно-морское сотрудничество, проведя серию тактических учений, которые по времени проведения совпали с празднованием 70-летия создания ВМС Китая, где кроме России присутствовали представители Таиланда, Вьетнама и Индии. В свою очередь, российский Тихоокеанский флот принял участие в российско-китайских учениях после проведения дружественных визитов во Вьетнам и на Филиппины [18]. Одновременно с увеличением количества военно-морских мероприятий России с этими странами можно говорить об активизации военного и особенно военно-морского сотрудничества с Таиландом, Мьянмой, Камбоджей и Лаосом. 
После выхода из проекта Транстихоокеанского партнерства и некоторого снижения интереса США к Азиатско-Тихоокеанскому региону военноморские учения и контакты вне зоны ответственности американского флота стали формой геополитической сигнализации великих держав региона (в первую очередь, России и Китая) о меняющемся в сторону азиатских государств балансе сил и угроз. Основной исследовательский вопрос заключается в том, является ли динамика военно-морского присутствия России в Юго-Восточной Азии в Индийском океане реакцией на изменившуюся стратегию США в Азии после смены политического руководства в 2017 г., попыткой упорядочить баланс сил с Китаем либо комбинацией этих интересов в сочетании с реагированием на другие вызовы региональной безопасности?

Аспекты военно-морского политического сотрудничества России со странами АТР рассмотрены в трудах таких исследователей как: А. Балыбердин, Чжао Кэцин, Чжан Хао, Д. Скотт, Э. Синконнен, Э. Вишник и т.д. Всесторонний анализ совместных учений России и Китая сделан Дэвидом Скоттом из Центра международной морской безопасности, который отмечает, что как «великие морские державы» Россия и Китай не только укрепляют безопасность в СевероВосточной Азии, но и влияют на расстановку сил на Корейском полуострове [6].

Сосредоточив внимание на военных аспектах российско-китайского партнерства, Э. Вишник характеризует визиты ВМФ России в Филиппины, Бирму и Вьетнам как фактор, сглаживающий углубление партнерства с Китаем. По словам Вишник, цель России состоит в том, чтобы диверсифицировать и расширить сотрудничество со странами Юго-Восточной Азии, а это потенциально обеспечит большую легитимность обеим странам в части их расширенного военного присутствия на море [9]. Э. Синконнен добавляет, что совместные военноморские учения с Россией помогают китайскому флоту приобретать опыт в районах, удаленных от прибрежных районов Китая [10].

Являясь сторонниками неореалистической парадигмы в международных отношениях, многие из исследователей уделяют большое внимание оценке двусторонних военно-морских отношений России с Китаем, однако не полностью учитывают динамику деятельности России в Юго-Восточной Азии и Индийском океане.

Цель данной работы состоит в исследовании особенностей военно-морского взаимодействия России с Индией, Вьетнамом, Филиппинами и другими странами ЮВА. Результатом этого взаимодействия является увеличение частоты, масштабов и диверсификации российской военно-морской деятельности в ЮгоВосточной Азии при сохранении динамики военно-морских контактов с Индией, что способствует поддержанию баланса сил в Азиатско-Тихоокеанском регионе. При этом уровень военно-морского взаимодействия между Россией и вышеуказанными странами непосредственно отражает уровень политического партнерства между ними.

Рассматривая подход к военно-морскому присутствию России в АТР с учетом ее национальной безопасности и национальных интересов, А. Балыбердин отмечает, что стратегическое взаимодействие с Китаем носит «приви- 
легированный характер» и является важным фактором экономической и политической безопасности России [1]. Чжао Кэцин и Хао Чжан добавляют, что обновленная российская военно-морская стратегия направлена на восстановление позиции России в числе «ведущих морских держав» АТР и вместе с тем испытывает гораздо меньше идеологических и исторических противоречий, чем в Европе [12]. Стратегия интеграции России в Азию дополняется более традиционной политикой баланса сил, в рамках которой Россия возвращается к ограниченному наращиванию обороны для защиты своих интересов.

В целом Россия проявляет твердую приверженность укреплению стратегического партнерства с Китаем в дополнение к общему плану двустороннего военного сотрудничества на 2017-2020 годы. Россия и Китай - приоритетные партнеры в продвижении принципов построения архитектуры неделимой безопасности и сотрудничества в АТР [2]. В то же время Москва непрерывно развивает военно-морское сотрудничество с Индией и Вьетнамом, которые все еще находятся в конфронтации с Пекином по различным вопросам региональной безопасности.

Одной из причин диверсифицированного подхода России к многостороннему сотрудничеству в Азии является желание уравновесить внешнеполитический курс КНР по продвижению проектов «Экономического пояса Шёлкового пути» и «Морского Шёлкового пути XXI века», посредством которого китайская сторона продвигает идеи подъема сотрудничества со странами Азии, Европы и Африки [3].

Россия и Индия. Индию можно назвать одним из самых давних партнеров России в области укрепления взаимной обороны. Начиная с середины 1960-х гг. Индия и Россия непрерывно развивают сотрудничество по безопасности, которое включает в себя и военно-морское сотрудничество. Интерес Индии к безопасности морских коммуникаций обусловлен, во-первых, выгодным географическим расположением основных линий морских коммуникаций (SLOC), во-вторых, быстрыми темпами экономического развития [11].

Практической основой военно-морского сотрудничества России и Индии служит серия межвидовых двусторонних учений «Индра», которые включают в себя как военно-морской, так и наземный этапы, чередующиеся с 2003 г. между сухопутными и военно-морскими силами (проводятся как межвидовые учения с 2014 г.). В дополнение к регулярной совместной подготовке экипажей во время посещения судов в портах друг друга с 2009 года российский ВМФ принимал участие в совместных морских тренировках с военно-морским флотом Индии у побережья Сомали.

Первые полномасштабные военно-морские учения «Индра» были проведены в 2003 г. в Индийском океане с участием кораблей Черноморского и Тихоокеанского флотов РФ. Совместно с кораблями ВМС Индии был выполнен ряд оперативных задач: совместное маневрирование, ракетно- 
артиллерийская стрельба по военно-морским и воздушным целям, учения по противолодочной обороне и помощь при бедствии на море.

В 2005 году на этих учениях Россия была представлена ракетным крейсером, большими противолодочными кораблями и ракетным эсминцем, а Индия выделила десять кораблей различного ранга. Основной целью учений была отработка элементов совместного противодействия военно-морских сил России и Индии террористическим угрозам в Бенгальском заливе. Были проведены артиллерийские и зенитные ракетные обстрелы, совместное маневрирование и пополнение запасов с моря.

Политическая ситуация в регионе, включая напряженные отношения Индии с Пакистаном, повлияли на сценарий учений, включающий совместный осмотр судна, на борту которого по легенде находились компоненты ядерного оружия. Основная политическая задача, реализуемая российским командованием: продемонстрировать, что Москва заинтересована и готова внести свой вклад в укрепление стабильности в Индо-Тихоокеанском регионе.

В последующие периоды в зависимости от региона проведения и политической обстановки сценарий учений «Индра» претерпевал различные изменения. В 2007 году учения по поисково-спасательным операциям в акватории залива Петра Великого были дополнены действиями тральщиков и сухопутных военно-морских сил. В 2009 и 2012 годах в связи с участием России и Индии в антипиратских операциях у побережья Африканского Рога были проведены совместные тренировки по освобождению и досмотру судна, условно захваченного террористическими формированиями. В 2009 году была отработана совместная высадка на борт судна, а в 2012 году - совместное маневрирование и артиллерийские стрельбы.

В 2014 году в рамках учений «Индра» три индийских и пять российских военных кораблей отработали совместную противолодочную, противовоздушную и противокорабельную оборону, вертолетные операции, помощь кораблю, терпящему бедствие, и пополнение запасов в Японском море. В рамках «Индры-2015» ВМФ РФ представляли ракетный крейсер, эсминец и вспомогательные суда. От ВМС Индии в учениях приняли участие дизельэлектрическая подводная лодка и пять надводных кораблей. Военно-морские силы осуществляли тактические маневры, инспекционные операции при поддержке вертолетов и наносили совместные ракетные и артиллерийские удары по морским и воздушным целям.

В 2017 году российско-индийские межвидовые учения были организованы в расширенном формате (одновременно на полигонах в Южном Приморье и в заливе Петра Великого в Японском море). Вместо отдельных военно-морских, воздушных и антитеррористических учений, состоявшихся в 2016 году («Индра-Нэви-2016», «Авиа-Индра-2016» и «Индра-2016»), учения проводились на основе общего сценария с участием ВМФ России, армейских подразделений и авиации, а также подразделений ВМС Индии и индийской армии. 
В рамках военно-морской фазы «Индра-2017» Россия и Индия отработали сопровождение судов, создание и обеспечение гуманитарных коридоров, а также задержание и досмотр судов, которые условно захвачены пиратскими группировками. Эти учения сопровождались практикой посадки и захвата береговой полосы с использованием десантных подразделений, а также поиском подводной лодки противника, элементами встречного морского боя, учениями морской авиации и т. д. [15]. По схожему сценарию планируется проводить последующие межвидовые учения, в частности «Индра2019».

Анализ показывает, что в течение длительного времени количество кораблей и судов, выделенных Россией и Индией для участия в учениях «Индра», оставалось практически неизменным (от двух до пяти кораблей и судов с каждой стороны). Основные цели обоих государств направлены на поддержание стратегического партнерства, демонстрацию флага в АзиатскоТихоокеанском регионе и проверку готовности сил соответствующего флота к действиям в прибрежных и океанских районах. Стоит также отметить сохраняющуюся зависимость Индии от России в военно-морском техническом сотрудничестве. Оно включает в себя эксплуатацию до 2022 г. Индией российской атомной подводной лодки «Нерпа», работу российских специалистов гарантийного обслуживания на переданном Индии авианосце «Викрамадитья», а также практику обменных программ обучения индийских офицеров в Российской Федерации.

Россия и Вьетнам. Как и в случае с Индией, военно-морское сотрудничество России и Вьетнама основано на исторически сформированных контактах в советский период. Однако в отличие от Индии ВМФ России не проводит полномасштабных морских учений с ВМС Вьетнама. Основным предметом переговоров до последнего времени являлся вопрос о возобновлении военно-морского присутствия России на бывшей арендуемой СССР во Вьетнаме военно-морской базе Камрань. Россия вывела оттуда свои военно-морские силы в начале 2000-х годов в рамках сокращения военного присутствия после распада Советского Союза.

Ввиду сближения военно-политических интересов Москвы и Ханоя на фоне сообщений и активизации сотрудничества между двумя военно-морскими силами интерес России к использованию Камрани как пункта материальнотехнического обеспечения (ПМТО) для российского ВМФ представлялся закономерным. Однако в 2016 г. министерство иностранных дел Вьетнама официально отказалось от политики использования своей территории третьими странами и взаимодействия с какой-либо страной для противодействия третьей стране [7].

В то же время в последние несколько лет военно-морское сотрудничество России и Вьетнама приобрело устойчивый военно-дипломатический характер. По сравнению с другими странами ЮВА усилилась его военно-техническая составляющая. Например, в 2017 г. ракетный крейсер ТОФ и вспомогательные корабли посетили Камрань с целью укрепления стратегического партнерства между 
двумя странами и подтверждения устойчивых контактов в области оборонного сотрудничества между военно-морскими силами. В начале того же года представители ВМС Вьетнама приняли участие в военно-морском параде в СанктПетербурге. В 2018 г. отряд противолодочных кораблей ТОФ снова посетили Камрань после встречи лидеров министерств обороны обеих стран.

После того как в июне 2017 года было ратифицировано соглашение об упрощенной процедуре захода военных кораблей в порты России и Вьетнама, Россия стала единственным государством, имеющим такое соглашение с Вьетнамом. Стоит отметить, что впоследствии Вьетнам подписал подобное соглашение об обслуживании вспомогательных кораблей ВМС США в Камрани, а министр обороны США посетил Вьетнам в марте 2019 года сразу после визита министра обороны России [17].

В соответствии с соглашением о военном сотрудничестве на 2018-2020 годы Россия и Вьетнам запланировали большое количество военно-морских учений, визитов вежливости и других совместных мероприятий, включая поисковоспасательные тренировки для оказания помощи подводным кораблям, терпящим бедствие. При этом в 2018-2020 годах Москва также запланировала более тесное военное сотрудничество с западным соседом Вьетнама Лаосом, подписав соответствующее соглашение во время седьмой Московской конференции по международной безопасности.

Таким образом, несмотря на более сдержанный курс в последние годы, Вьетнам можно назвать важным перспективным элементом тихоокеанской стратегии России по созданию военно-морских объектов для ремонта, снабжения и технического обслуживания российских кораблей и судов. Усиливая свое военно-морское присутствие во Вьетнаме, Россия демонстрирует заинтересованность в восстановлении глобального военно-морского присутствия в тех традиционных зонах, где ранее присутствовал ВМФ СССР.

Стимулирующим фактором на этом направлении выступает то, что Вьетнам активно проводит модернизацию большинства надводных кораблей и катеров. В рамках «стратегии противодействия иностранному вмешательству» ВМС Вьетнама стали одним из наиболее активных заказчиков российского военноморского оборудования, в том числе шести малошумных дизельных подводных лодок класса «Варшавянка» [8]. Другой элемент этой программы - продолжение совместной программы строительства ракетных и скоростных патрульных катеров, создания мест базирования и инфраструктуры. Необходимо отметить, что Вьетнам проявляет интерес к повышению потенциала ПВО своих ВМС, а также проведению операций по проводке судов и установке минных заграждений. В пример можно привести серию из двух российских фрегатов проекта $11661 \mathrm{E}$, запущенную в 2016 году для ВМС Вьетнама и введенную в эксплуатацию в 2018 году, которая отвечает этим задачам.

Новая дорожная карта военно-морского сотрудничества с Вьетнамом, тем не менее, может повлиять на нейтральную роль Москвы в продолжающейся борьбе за стратегическое превосходство между Китаем и США в Южно-Китайском море [6], а также стать причиной осложнений отношений России с Китаем, т.к. Вьет- 
нам является одним из основных участников споров с Китаем по вопросу островных территорий Южно-Китайского моря.

Россия и Филиппины. В отличие от Вьетнама, Филиппины, будучи союзником США, исторически не были советским и российским партнером в области безопасности, однако всегда оставались в центре внимания. Так, президент Филиппин Р. Дутерте стремился диверсифицировать связи своей страны с Вашингтоном, учитывая отсутствие «политических обстоятельств» [14]. Последние несколько лет ВМФ РФ регулярно посещает Филиппины, что связано как с дипломатическими целями, так и с участием России в модернизации филиппинских вооруженных сил. В апреле 2017 г., незадолго до того, как Р. Дутерте посетил Россию в мае для подписания соглашения о сотрудничестве в области обороны, отряд кораблей ТОФ нанес визит вежливости в столицу Филиппин Манилу. Позднее в октябре 2017 г. военные корабли российского Тихоокеанского флота снова посетили Филиппины для обеспечения безвозмездной поставки 5000 штурмовых винтовок АК-74М, а также боеприпасов, армейских грузовиков и стальных шлемов. Позже Р. Дутерте поручил министру обороны проработать вопрос о приобретении у России и другого современного военного оборудования: беспилотные летательные аппараты (БПЛА), приборы ночного видения, снайперские винтовки, вертолеты и т.д. [16].

В 2019 г. два противолодочных корабля ТОФ и танкер обеспечения пришвартовались на Филиппинах в период ежегодных совместных учений Филиппин и США «Баликатан». При этом, отреагировав на известие о прибытии российского ВМФ в Манилу, США напомнили, что «отношения в области безопасности между Соединенными Штатами и Филиппинами остаются долгосрочными и прочными» [18].

Таким образом, Россия укрепляет свои позиции в качестве одного из ведущих поставщиков военно-морского и другого вооружения в АТР, в том числе активизируя сотрудничество в областях, где страны Юго-Восточной Азии ранее традиционно тесно сотрудничали с США. Кроме того, Россия предоставляет определенную долю военной помощи, которую оказывают Соединенные Штаты, но не связывает страны долгосрочными стратегическими обязательствами в рамках союзных отношений.

Филиппины рассматривают Россию не только как дружественное государство, но и как защитника своих интересов в противодействии экстремизму и пиратству посредством обмена разведданными, совместных тренировок и т.д., с учетом укрепления тесного сотрудничества в военной сфере. С другой стороны, полномасштабные военно-морские учения между двумя странами маловероятны, поскольку ВМФ РФ использует собственную систему сигналов, которая затрудняет связь с другими флотами при непосредственной совместной работе [4]. Кроме того, уровень взаимодействия, необходимый для проведения совместных учений, которого Россия достигла с Китаем благодаря долгосрочному сотрудничеству, пока является недостижимым для Филиппин.

Стоит отметить, что укрепление морских связей между Москвой и Манилой также отражается на интернационализации локальных споров в Южно- 
Китайском море, увеличивая тем самым опасность столкновения тихоокеанских сфер влияния России с такими странами, как Китай. Тем не менее, Россия пока не сильно заинтересована в подобных спорах, поскольку российское военноморское присутствие в Южно-Китайском море сильно ограничено по сравнению с Китаем, Японией или США.

Россия в Юго-Восточной Азии. В последние годы военные корабли ТОФ также посетили порты Камбоджи, Брунея, Таиланда, Сингапура, Мьянмы и т.д. Отметим, что важность активизации военно-морского сотрудничества России в Юго-Восточной Азии выходит за пределы исключительно визитов и охватывает широкий круг дипломатических и технических задач.

По словам редактора издания The Diplomat и эксперта по вопросам безопасности в Юго-Восточной Азии Прашанта Парамесварана, Таиланд является одной из ключевых стран, с которыми Россия стремится укрепить оборонные связи, приводя в пример обмен опытом в рамках антитеррористических и антипиратских учений. Несмотря на то, что Таиланд - традиционный союзник США в ATP, сотрудничество между Москвой и Бангкоком в военной сфере имеет в последние годы устойчивую растущую динамику.

Во-первых, в 2017 г. было заключено межправительственное соглашение о военном сотрудничестве по закупке российской военной техники. Во-вторых, в 2017 г. состоялся визит кораблей ТОФ в Таиланд с целью проведения серии памятных военных мероприятий в связи с 50-летием АСЕАН. Они включали в себя проведение Международного военно-морского смотра (IFR) и связанных с ним мероприятий в районе залива Паттайя.

Во время посещения Сингапура в том же году российские военные корабли приняли участие в праздновании 50-летия ВМФ республики, выставке морской обороны IMDEX Asia, а также в многосторонних военно-морских учениях «KOMODO», которые прошли за год до участия России в Еxро Indo Defense в Индонезии. Стоит также отметить участие ТОФ РФ в антитеррористических учениях «SMOA», совместных учениях по маневрированию российских, сингапурских и индонезийских военных кораблей, а также учениях военно-морских сил России и Брунея «PASSEX», проведенных в 2016 и 2017 годах соответственно.

Взаимодействие российского флота с ВМС Камбоджи ориентировано на налаживание военно-морских связей между двумя странами и укрепление роли Москвы в Юго-Восточной Азии в целом. Оборонный аспект этих связей развивается медленнее, включая в основном дружественные визиты. Например, отряд кораблей и судов снабжения Тихоокеанского флота посетил камбоджийскую ВМБ «Сиануквиль» в ноябре 2017 года. Стоит отметить, что российские визиты в Камбоджу нельзя назвать чем-то особенным, они, исключая элемент совместных тренировок, являются частью запланированных мероприятий ВМФ РФ по демонстрации флага в АТР [13].

Что касается Мьянмы, российские военные корабли совершали визиты в порты этой страны в 2013, 2016 и 2017 годах, дополняя взаимодействие между двумя странами в обороне. Основной интерес Мьянмы в таких визитах связан 
А.С. Голобоков. Основные тенденции военно-политического сотрудничества России...

с потенциальной поддержкой и противодействием угрозе выхода антиправительственных этнических групп на севере страны. Интерес России к Мьянме обусловлен диверсификацией внешнеполитических военных связей за рамками КНР. Кроме того, Мьянма после Вьетнама является вторым по величине перспективным рынком для российского вооружения в Юго-Восточной Азии.

Так, военно-воздушные силы Мьянмы в последние несколько лет приобрели 21 российский вертолет, а общая стоимость контрактов на приобретение российских вооружений и военной техники для Мьянмы, включая подготовку военного персонала (1,45 млрд долларов с 2001 по 2016 год), превысила объем китайских контрактов в этой стране (1,42 млрд долларов) [9].

Отношения между Россией и Мьянмой в области обороны стали более заметны, после того как правительство этой страны, будучи связанным санкциями Запада и ограниченным в приобретении вооружений у стран, начало рассматривать Россию как партнера в оборонной сфере. В целом же сфера действия двустороннего оборонного соглашения между РФ и Мьянмой широка и охватывает не только военно-морское сотрудничество, но и миротворчество, поисковоспасательные операции, обмен информацией о международной безопасности и борьбу с терроризмом.

Заключение. Динамика российского военно-морского присутствия в ЮгоВосточной Азии и, в частности, увеличение числа учений и дипломатических военно-морских визитов ВМФ РФ в порты вышеупомянутых стран свидетельствуют о повышении активности России в Индо-Тихоокеанском регионе. Одним из катализаторов этого явления можно назвать стремление Москвы частично сбалансировать влияние индо-тихоокеанской политики США, которые после выхода президента Д. Трампа продолжают поддерживать высокий уровень военно-морской активности в АТР, в одностороннем, двустороннем и многостороннем форматах.

Несмотря на то, что Россия постоянно усложняет тематику и этапы совместных учений, в целом по количеству и масштабу серии военно-морских маневров, организуемых США и их партнерами по АТР, происходят значительно чаще. Кроме того, по сравнению с интересами Китая и США интересы России в области морской безопасности в ЮВА (Южно-Китайское море) в достаточной степени ограничены. Россия не проводит там полномасштабных учений; тем не менее, ее участие стало более заметным, что подтверждает динамика военноморских контактов с Вьетнамом, Филиппинами, Мьянмой и т.д.

Говоря о причинах данной тенденции, отметим, что Россия, во-первых, стремится избавиться от второстепенной роли в Юго-Восточной Азии, обеспечивая военно-морское присутствие и демонстрацию флага. Во-вторых, стремясь диверсифицировать и расширить морское сотрудничество со всеми странами ЮВА, Россия следует положениям своей морской стратегии. В этом отношении влияние военно-морской дипломатии не только демонстрирует интерес в многосторонних контактах, не ограничиваясь российско-китайскими учениями и визитами; но и оказывает влияние на региональную безопасность и баланс сил в регионе, способствует поддержанию баланса сил в Азии. В-третьих, динамика 
военно-морских контактов России в ЮВА указывает на сохранение боевой готовности российских военных кораблей и подразделений, в том числе в составе совместных тактических групп. Одновременно с укреплением стратегического партнерства между Китаем и Россией уровень взаимодействия России со странами ЮВА напрямую отражает уровень политического партнерства.

Военно-морские контакты России и Индии испытывают стабильную динамику (районы учений, перечень выполненных оперативных задач, количество и соотношение судов и т. д.) существенно не менялись на протяжении нескольких лет. Такая ситуация позволяет, с одной стороны, поддерживать стратегическое партнерство, а с другой - не вызывать геополитического недовольства других стратегических партнеров (например, Китая для России и США для Индии).

1. Балыбердин А. Морская доктрина в новой редакции // Морские вести России. 2015. № 10 .

2. Голобоков А.С., Караева А.С. Российско-китайское торгово-экономическое сотрудничество и его роль в развитии российского Дальнего Востока // Азимут научных исследований: экономика и управление. 2016. Т. 5, № 4 (17). С. 114-117.

3. Медведева Л.М., Голобоков А.С., Лаврентьев А.В. Анализ российско-китайских отношений в контексте стратегий регионального экономического развития // Азимут научных исследований: экономика и управление. 2016. Т. 5, № 4 (17). С. 280-285.

4. Brad Lendon. Russian warships visit Philippines; admiral suggests wider exercises// CNN. URL: https://edition.cnn.com/2017/01/03/asia/russia-philippines-exercises-south-china-sea (дата обращения 10.11.2019).

5. David Brennan. Russia to Join U.S.-China South China Sea Face Off After Vietnam Pact // Newsweek. URL: https://www.yahoo.com/news/russia-join-u-china-south-161047537.html (дата обращения 12.11.2019).

6. David Scott. Russia-China Naval Cooperation In An Era Of Great Power Competition// Center for International Maritime Security. URL: http://cimsec.org/russia-china-navalcooperation-in-an-era-of-great-power-competition/36773 (дата обращения 11.11.2019).

7. Vietnam says no to foreign military base on its soil. URL: https://www.reuters.com/article/us-vietnam-russia-military-idUSKCN12D15S (дата обращения 15.11.2019).

8. Carlyle Thayer. Vietnam's Strategy of 'Cooperating and Struggling' with China over Maritime Disputes in the South China Sea // Journal of Asian Security and International Affairs. 2016. № 2. P. 213.

9. Elizabeth Wishnick. The Sino-Russian Partnership and the East Asian Order// Asian Perspective. 2018. № 42. P. 355-386.

10. Elina Sinkkonen. China-Russia Security Cooperation: Geopolitical Signalling With Limits. URL: FIIA, https://storage.googleapis.com/upi-live/2018/01/bp231_china-russia.pdf (дата обращения 16.11.2019).

11. Henry Ryan, Christine Osowski, Peter Chalk, James T. Bartis. Current Sea-Lane Security Capabilities and Mechanisms// In Promoting International Energy Security. 2012. Vol. 3: Sea-Lanes to Asia. P. 21-36.

12. Kejin Zhao, Hao Zhang. Projecting Political Power: China's Changing Maritime Strategy// The Chinese Journal of International Politics. 2019. Vol. 12. P. 229-261.

13. Prashanth Parameswaran. What's Behind the Russian Warship Visit to Cambodia? // The Diplomat. URL: https://thediplomat.com/2017/11/whats-behind-the-russian-warship-visitto-cambodia/ (дата обращения 16.11.2019). 
14. Prashanth Parameswaran. Where Are Russia-Philippines Defense Ties Under Duterte? URL: https://thediplomat.com/2017/10/where-are-russia-philippines-defense-ties-underduterte/ (дата обращения 12.11.2019).

15. Russia, India to Train Naval, Air Blockade During Joint Exercises Indra-2017 [in Russian]// Sputnik. URL: https://sputniknews.com/world/201708071056250347-russia-indiaindra-2017/ (дата обращения 13.11.2019).

16. Russian Navy delivers military arms to Philippines// The Associated Press. URL: https://www.defensenews.com/global/asia-pacific/2017/10/20/russian-navy-deliversmilitary-arms-to-philippines/ (дата обращения 19.11.2019).

17. The US Defense Secretary's Visit To Vietnam, Embassy Of Socialist Republic Of Vietnam In The United States Of America. URL: http://vietnamembassy-usa.org/relations/usdefense-secretarys-visit-vietnam (дата обращения 11.11.2019).

18. The Sino-Russian maritime joint performance came: close to the actual combat submarine participation in the attention [in Chinese] // Huanqiu. URL: http://mil.huanqiu.com/world/2019-04/14809052.html?agt=5549 (дата обращения 15.11.2019).

19. US 'closely tracking' as Chinese navy in the Baltics for war games with Russia// The Telegraph. URL: http://www.telegraph.co.uk/news/2017/07/21/us-closely-tracking-chinesenavy-baltics-war-games-russia/ (дата обращения 15.11.2019).

\section{Транслитерация}

1. Balyberdin A. Morskaya doktrina v novoj redakcii // Morskie vesti Rossii. 2015. № 10.

2. Golobokov A.S., Karaeva A.S. Rossijsko-kitajskoe torgovo-ekonomicheskoe sotrudnichestvo i ego rol' v razvitii rossijskogo Dal'nego Vostoka // Azimut nauchnyh issledovanij: ekonomika i upravlenie. 2016. T. 5. № 4 (17). P. 114-117.

3. Medvedeva L.M., Golobokov A.S., Lavrent'ev A.V. Analiz rossijsko-kitajskih otnoshenij v kontekste strategij regional'nogo ekonomicheskogo razvitiya // Azimut nauchnyh issledovanij: ekonomika i upravlenie. 2016. T. 5. № 4 (17). P. 280-285.

() А.С. Голобоков, 2019

Для цитирования: Голобоков А.С. Основные тенденции военно-политического сотрудничества России с Индией и странами Юго-Восточной Азии // Территория новых возможностей. Вестник Владивостокского государственного университета экономики и сервиса. 2019. Т. 11, № 4. С. 128-139.

For citation: Golobokov A.S. The main trends of Russia's military-political cooperation with India and Southeast Asian countries, The Territory of New Opportunities. The Herald of Vladivostok State University of Economics and Service, 2019, Vol. 11, № 4, pp. 128-139.

DOI dx.doi.org/10.24866/VVSU/2073-3984/2019-4/128-139

Дата поступления: 28.11.2019. 